\title{
GAMBARAN FOTO WATERS PADA PENDERITA DENGAN DUGAAN KLINIS SINUSITIS MAKSILARIS DI BAGIAN RADIOLOGI FK UNSRAT/SMF RADIOLOGI BLU RSUP PROF. Dr. R. D. KANDOU MANADO PERIODE 1 JANUARI 2011-31 DESEMBER 2011
}

\author{
${ }^{1}$ Allan Hespie Posumah \\ ${ }^{2}$ Ramli Hadji Ali \\ ${ }^{2}$ Elvie Loho
}

\author{
${ }^{1}$ Kandidat Skripsi Fakultas Kedokteran Universitas Sam Ratulangi Manado \\ ${ }^{2}$ Bagian Radiologi Fakultas Kedokteran Universitas Sam Ratulangi Manado \\ Email: allan161@yahoo.com
}

\begin{abstract}
Sinusitis is an inflammation of the mucous membranes that can be on one or several paranasal sinuses, and the most commonly affected are the maxillary sinus and etmoidalis sinus. An anamnesis and physical examination can already diagnonse suspect of maxillary sinusitis. Radiological examination perfomed to get an early diagnose. Photo Waters is one of the best examination because can already diagnose an abnormality in maxillary sinus with $85 \%$ and $80 \%$ sensivity and specifity. This study aims is to know the description of Photo Waters in patient with suspect of maxillary sinusitis based on age, sex, and description of Photo Waters in Radiology Department of BLU Prof. Dr. R. D. Manado Kandou within period 1st January 2011 to 31 st December 2011. This research is retrospective descriptive study. The data was a request and answer form of Photo Waters in Radiology Department and analyze in descriptive form. The number of patients with maxillary sinusitis radiology diagnose in the Radiology Department of BLU Prof. Dr. R.D. Kandou are 60 patients. Most cases are women in the amount of $56.67 \%$, with $30-40$ years age is the most common. With the results of description of Photo Waters in poor veil image is $71.67 \%$.
\end{abstract}

Keywords: Maxillary sinus, Photo Waters, sinusitis.

\begin{abstract}
Abstrak: Sinusitis merupakan suatu peradangan membran mukosa yang dapat mengenai satu ataupun beberapa sinus paranasal, dan yang paling sering terkena yaitu sinus maksilaris dan sinus etmoidalis. Anamnesis dan pemeriksaan fisik sudah dapat mencurigai adanya sinusitis maksilaris. Untuk mendapatkan diagnosis yang lebih dini diperlukan pemeriksaan radiologis. Foto Waters merupakan pemeriksaan yang paling baik karena sudah mampu mendiagnosis suatu kelainan di sinus maksilaris dengan sensitifitas dan spesifisitas yaitu $85 \%$ dan $80 \%$. Tujuan penelitian ini adalah untuk mengetahui gambaran Foto Waters pada penderita dengan dugaan klinis sinusitis maksilaris berdasarkan jenis kelamin, umur, dan hasil gambaran Foto Waters di Bagian Radiologi BLU Prof. Dr. R. D. Kandou Manado Periode 1 Januari-31 Desember 2011. Penelitian ini merupakan penelitian deskriptif retrospektif. Data berupa lembaran permintaan dan jawaban Foto Waters di Bagian Radiologi dan diolah dalam bentuk deskriptif. Jumlah penderita dengan diagnosis radiologis sinusitis maksilaris di Bagian Radiologi BLU RSUP Prof. Dr. R.D. Kandou sebanyak 60 penderita. Kebanyakan kasus adalah perempuan yaitu sebesar 56,67\%, dengan umur tebanyak 30-40 tahun. Dengan hasil gambaran Foto Waters terbanyak pada gambaran perselubungan yaitu 71,67\%.
\end{abstract}

Kata kunci: Foto Waters, sinus maksilaris, sinusitis. 
Sinusitis merupakan penyakit yang sering ditemukan dalam praktek dokter seharihari, bahkan dianggap salah satu penyebab gangguan kesehatan tersering di seluruh dunia. ${ }^{1}$ Sinusitis merupakan suatu peradangan membran mukosa yang dapat mengenai satu ataupun beberapa sinus paranasal. ${ }^{2}$ Sinus paranasal merupakan ronggarongga disekitar hidung dengan bentuk bervariasi dan terdiri dari empat pasang sinus, yaitu sinus maksilaris, sinus frontalis, sinus etmoidalis, dan sinus sfenoidalis. Berdasarkan perjalanan penyakitnya, infeksi dapat berlangsung akut maupun kronis, dengan batasan waktu kurang atau lebih dari 12 minggu dan penyebab utama ialah selesma yang merupakan infeksi virus, yang selanjutnya dapat diikuti dengan infeksi bakteri. Sebagian besar kasus sinusitis melibatkan lebih dari satu sinus paranasal dan yang paling sering yaitu sinus maksilaris dan sinus etmoidalis. ${ }^{3,4}$

Insidens sinusitis merupakan penyakit yang cukup parah yang membuat orang memeriksakan diri ke dokter yaitu antara 1,3 dan 3,5 per 100 kasus orang dewasa per tahun. Peneliti dari Norwegia mengemukakan insidens sinusitis yaitu 3,5 per 100 kasus pada orang dewasa dengan 7\% pasien memiliki dua kali kunjungan dan 0,5\% memiliki tiga kali atau lebih kunjungan selama periode 12 bulan. $^{5}$ Di Amerika, insidensi sinusitis sekitar 20 juta orang per tahun dengan 18 juta orang yang melakukan pemeriksaan. ${ }^{6}$

Data dari DEPKES RI (2003) menyebutkan bahwa penyakit hidung dan sinus berada pada urutan ke- 25 dari 50 pola penyakit peringkat utama atau sekitar 102.817 penderita rawat jalan di rumah sakit. Di Indonesia data dari Divisi Rinologi Departemen THT RSCM Januari-Agustus 2005 menyebutkan jumlah pasien rinologi pada kurun waktu tersebut sebanyak 435 pasien dan 69\% (300 pasien) adalah sinusitis. ${ }^{7} \mathrm{Di}$ Bagian Poliklinik THT RSUP Prof. Dr. R. D. Kandou Manado (1995) menyebutkan sinusitis maksilaris berada pada urutan ke tiga dari 10 penyakit hidung terbanyak dan jumlah pasien rinologi pada kurun waktu tersebut sebanyak 1676 pasien, dan $16 \%$
(268 pasien) merupakan sinusitis maksilaris. $^{8}$

Keluhan utama pasien berupa hidung tersumbat dan disertai dengan nyeri tekan pada pipi dan ingus purulen, bisa disertai dengan gejala sistemik seperti demam dan letargi. Pada sinusitis maksilaris terdapat nyeri tekan pada pipi dan nyeri ketok pada gigi. Gejala lain ialah sakit kepala, hiposmia/anosmia, halitosis. ${ }^{9,10}$

Ada begitu banyak pemeriksaan untuk mendiagnosis sinusitis maksilaris. Anamnesis dan pemeriksaan fisik sudah dapat mencurigai adanya sinusitis maksilaris, tapi untuk memberikan diagnosis yang lebih dini, maka diperlukan pemeriksaan radiologis. Pemeriskaan radiologis dari sinusitis maksilaris sering menggunakan Foto Waters, CT Scan, dan MRI. ${ }^{11}$

Pemeriksaan Foto Waters merupakan pemeriksaan yang paling baik untuk mengevaluasi sinus maksilaris. William et al (1992), menyimpulkan bahwa Foto Waters dapat diterima untuk mendiagnosis suatu kelainan di sinus maksilaris. Pemeriksaan ini dari sudut biaya cukup ekonomis dan pasien hanya mendapat radiasi yang minimal. Sensitifitas dan spesifisitasnya yaitu $85 \%$ dan $80 \%$. Berdasarkan gambaran radiologis dengan Foto Waters dapat menilai kondisi sinus maksilaris yang memperlihatkan perselubungan, air fluid level, dan penebalan mukosa. ${ }^{11}$

Banyaknya penderita dengan dugaan klinis sinusitis maksilaris dan permintaan Foto Waters di Bagian Radiologi BLU RSUP Prof. Dr. R. D. Kandou Manado mendorong penulis untuk melakukan penelitian, sebab penelitian mengenai radiologis sinusitis maksilaris belum pernah dilakukan. Selain itu penelitian ini dapat mengetahui dan mempelajari gambaran radiologis pada penderita dengan dugaan klinis sinusitis maksilaris di Bagian Radiologi BLU RSUP. Prof. Dr. R. D. Kandou Manado periode 1 januari 2011-31 desember 2011.

Penelitian ini untuk mengetahui bagaimana gambaran Foto Waters pada penderita dengan dugaan klinis sinusitis maksilaris di Bagian Radiologi FK 
Unsrat/SMF Radiologi BLU RSUP Prof. Dr. R. D. Kandou Manado Periode 1 Januari 2011-31 Desember dan bagaimana presentase penderita sinusitis maksilaris di Bagian Radiologi FK Unsrat/SMF Radiologi BLU RSUP Prof. Dr. R. D. Kandou Manado Periode 1 Januari 2011-31 Desember 2011 ?

\section{METODE}

Penelitian ini merupakan penelitian deskriptif retrospektif dengan memanfaatkan data sekunder berupa lembaran permintaan dan jawaban Foto Waters di Bagian Radiologi dan diolah dalam bentuk deskriptif. Waktu penelitian berlangsung dari bulan November-Desember 2012. Populasi pada penelitian ini yaitu semua lembaran permintaan dan jawaban Foto Waters di bagian Radiologi BLU RSUP Prof. Dr. R. D. Kandou Manado Periode 1 Januari-31 Desember 2011, sedangkan sampelnya yaitu semua lembaran permintaan dan jawaban Foto Waters penderita dengan dugaan klinis sinusitis maksilaris di bagian Radiologi BLU RSUP Prof. Dr. R. D. Kandou Manado Periode 1 Januari-31 Desember 2011.

\section{HASIL}

Selama periode 1 Januari 2011-31 Desember 2011, didapatkan jumlah penderita dengan dugaan klinis Sinusitis Maksilaris yang melakukan pemeriksaan Foto Waters di Bagian Radiologi BLU RSUP Prof. Dr. R. D. Kandou sebanyak 97 penderita.

Tabel 1. Distribusi presentase penderita sinusitis maksilaris.

\begin{tabular}{ccc}
\hline Diagnosis radiologi & $\mathbf{n}$ & $\mathbf{\%}$ \\
\hline Sinusitis maksilaris & 60 & 61,86 \\
Tak ada kelainan & 37 & 38,14 \\
\hline Jumlah & $\mathbf{9 7}$ & $\mathbf{1 0 0}$ \\
\hline
\end{tabular}

Dari tabel 1 didapatkan sebanyak 60 orang $(61,86 \%)$ dengan diagnosis sinusitis maksilaris dan tidak ada kelainan sebanyak 37 orang $(38,14 \%)$.
Tabel 2. Distribusi jenis kelamin penderita sinusitis maksilaris.

\begin{tabular}{ccc}
\hline Jenis Kelamin & $\mathbf{N}$ & $\mathbf{\%}$ \\
\hline Laki-laki & 26 & 43,33 \\
Perempuan & 34 & 56,67 \\
\hline Jumlah & $\mathbf{6 0}$ & $\mathbf{1 0 0}$ \\
\hline
\end{tabular}

Dari tabel 2 didapatkan penderita sinusitis maksilaris terbanyak pada perempuan yaitu 34 penderita $(56,67 \%)$. Dan pada laki-laki sebanyak 26 penderita $(43,33 \%)$.

Tabel 3. Distribusi umur penderita sinusitis maksilaris.

\begin{tabular}{ccc}
\hline Umur (tahun) & $\mathbf{N}$ & $\mathbf{\%}$ \\
\hline $0-14$ & 5 & 8,33 \\
$15-29$ & 6 & 10 \\
$30-44$ & 24 & 40 \\
$45-59$ & 20 & 33,33 \\
$\geq 60$ & 5 & 8,33 \\
\hline Jumlah & $\mathbf{6 0}$ & $\mathbf{1 0 0}$ \\
\hline
\end{tabular}

Dari tabel 3 didapatkan presentasi tertinggi penderita sinusitis maksilaris terdapat kelompok umur 30-44 sebanyak 24 orang penderita $(40 \%)$ dan yang paling sedikit pada kelompok umur 0-14 dan $\geq 60$ yaitu 5 penderita.

Tabel 4. Distribusi gambaran Foto Waters penderita sinusitis maksilaris.

\begin{tabular}{ccc}
\hline $\begin{array}{c}\text { Gambaran } \\
\text { Foto Waters }\end{array}$ & $\mathbf{n}$ & $\mathbf{\%}$ \\
\hline Penebalan Mukosa & 17 & 28,33 \\
Air fluid level & 0 & 0 \\
Perselubungan & 43 & 71,67 \\
\hline Jumlah & $\mathbf{6 0}$ & $\mathbf{1 0 0}$ \\
\hline
\end{tabular}

Dari tabel 4.4. didapatkan gambaran Foto Waters yang terbanyak adalah perselubungan sebanyak 43 penderita (76,67\%). Dan tidak ditemukan gambaran air fluid level pada penderita sinusitis maksilaris. 


\section{BAHASAN}

Sesuai hasil penelitian yang dilakukan secara deskriptif retrospektif, jumlah pasien yang melakukan pemeriksaan Foto Waters dengan dugaan klinis sinusitis maksilaris di Bagian Radiologi BLU RSUP Prof. Dr. R. D. Kandou Manado periode 1 Januari 2011-31 Desember 2011 sebanyak 97 penderita, dengan sinusitis maksilaris sebanyak 60 penderita $(61,86 \%)$ dan tidak ada kelainan sebanyak 37 penderita $(38,14 \%)$. Hasil ini tidak berbeda jauh dengan hasil penelitian yang dilakukan Paramita (2010) yang mendapatkan sebanyak 91 penderita yang melakukan pemeriksaan Foto Waters dengan sinusitis maksilaris sebanyak 46 orang (51\%) dan Dalimunthe (2010) yang mendapatkan sebanyak 96 kasus, dengan sinusitis maksilaris sebanyak 62 penderita $(64,6 \%){ }^{13}$ Hal ini sesuai dengan kepustakaan yang mengatakan bahwa kasus sinusitis yang paling sering terkena yaitu sinus maksilaris dan sinus etmoidalis. ${ }^{1}$

Berdasarkan jenis kelamin (Tabel 4.2), dari penelitian ini didapatkan penderita dengan sinusitis maksilaris terbanyak pada perempuan yaitu 34 penderita $(56,67 \%)$, sedangkan pada laki-laki sebanyak 26 penderita (43,33\%). Vogen et al (2000) Pennsylvania mendapatkan dari 16 penderita sinusitis dalam penelitiannya didapatkan perempuan sebanyak sembilan penderita $(56,3 \%)$ dan laki-laki sebanyak tujuh penderita (43,7\%). Krzeski (2001) Polandia, dalam penelitiannya pada 157 penderita sinusitis didapatkan penderita perempuan sebanyak 88 penderita $(56 \%)$ dan laki-laki sebanyak 69 penderita (44\%). Nasution (2007), dalam penelitiannya pada 30 penderita didapatkan perempuan sebanyak 18 penderita $(60 \%)$ dan laki-laki sebanyak 12 penderita (40\%). Dari data diatas tampak penelitian ini tidak jauh berbeda dari penelitian sebelumnya yang mendapatkan kelompok perempuan paling banyak dibandingkan dengan laki-laki. Banyaknya penderita perempuan dimungkinkan karena yang datang berobat lebih banyak perempuan dan pada umumnya perempuan lebih peduli dengan keluhan sakit sehingga lebih cepat datang berobat. ${ }^{12}$

Berdasarkan kelompok umur (Tabel 4.3), dari penelitian ini didapatkan penderita dengan sinusitis maksilaris terbanyak yaitu pada kelompok umur 30-44 tahun sebanyak 24 penderita (40\%). Yoshiura et al (1993) di Jepang mendapatkan dari 68 penderita sinusitis yang ditelitinya, rata-rata usia penderita terbanyak pada usia 46 tahun. Elfahmi (2001) mendapatkan umur terbanyak pada usia 35-44 tahun sebanyak $30 \%$. Triolit Z (2004) mendapatkan umur terbanyak adalah 38-47 sebanyak 36,6\%. Nasution (2007) mendapatkan umur terbanyak pada usia 37-46 tahun sebanyak $33,3 \%$. Hasil yang didapat peneliti, terlihat umur terbanyak hampir sama serta tidak berbeda jauh dengan peneliti-peneliti lainnya. ${ }^{12}$ Dari data diatas didapati bahwa penderita terbanyak pada usia dewasa. Dalimunthe (2010) menyatakan hal tersebut mungkin disebabkan kelompok usia dewasa merupakan kelompok usia yang aktif dan sering terpapar oleh polutan atau zatzat iritan yang mungkin dapat menyebabkan atau memperberat terjadinya sinusitis maksilaris, sehingga lebih banyak penderita dengan kelompok usia dewasa yang datang berobat ke rumah sakit. ${ }^{15}$

Berdasarkan hasil gambaran Foto Waters (Tabel 4.4), dari penelitian ini didapatkan penderita dengan sinusitis maksilaris terbanyak dengan gambaran perselubungan sebanyak 43 penderita $(76,67 \%)$, 17 penderita $(28,33 \%)$ dengan gambaran penebalan mukosa dan tidak ditemukan gambaran air fluid level. Elfahmi (2001) mendapatkan gambaran perselubungan sebanyak $57,50 \%$, penebalan mukosa sebanyak $35 \%$ dan air-fluid level sebanyak 7,50\%. Hasil dari kedua penelitian ini hampir sama yaitu yang terbanyak ialah gambaran yang memperlihatkan adanya perselubungan dan yang paling sedikit adalah air fluid level. ${ }^{14}$ Sesuai dengan kepustakaan yang mengatakan pada pencitraan Foto Waters akan memperlihatkan gambaran penebalan mukosa, air fluid level, dan perselubungan homogen atau tidak homogen pada sinus maksilaris. ${ }^{11}$ 


\section{SIMPULAN}

Berdasarkan hasil penelitian yang dilakukan di Bagian Radiologi BLU RSUP Prof. Dr. R. D. Kandou Manado periode 1 januari 2011-31 desember 2011 mengenai gambaran Foto Waters pada penderita dengan dugaan klinis sinusitis maksilaris dapat disimpulkan bahwa jumlah penderita yang melakukan pemeriksaan Foto Waters dengan dugaan klinis sinusitis maksilaris sebanyak 97 penderita dan jumlah penderita dengan diagnosis radiologis sinusitis maksilaris sebanyak 60 penderita, perempuan lebih banyak dibandingkan laki-laki dengan perbandingan masing-masing $56,67 \%$ dan $43,33 \%$ dan terbanyak pada golongan umur 30-44 tahun. Dari hasil gambaran Foto Waters yaitu terbanyak pada gambar-an perselubungan $(71,67 \%)$, gambaran pe-nebalan mukosa $(28,33 \%)$ dan yang paling sedikit ada pada gambaran air fluid level $(0 \%)$.

\section{SARAN}

Perlu dilakukan edukasi kepada masyarakat tentang masalah-masalah yang mungkin timbul akibat sinusitis maksilaris sehingga penderita dapat berobat lebih awal dan untuk pemeriksaan Foto Waters, sebaiknya dilakukan dalam posisi yang dimodifikasi dalam hal ini posisi duduk, supaya dapat menilai gambaran air fluid level.

\section{UCAPAN TERIMA KASIH}

Penulis mengucapkan terima kasih sebesar-besarnya kepada dr. Olivia C. Pelealu, SpTHT-KL dan dr. Julied Dehoop, MPd,Ked selaku penguji 1 dan penguji 2 atas masukan dan saran dan kepada pihakpihak yang secara langsung atau tidak langsung telah memberikan gagasan dan ide kepada penulis.

\section{DAFTAR PUSTAKA}

1. Mangunkusomo E, Soetjipto D. Dalam: Soepardi EA, Iskandar N, Bashiruddin J, Restuti RD. Buku ajar ilmu kesehatan telinga hidung tenggorok kepala dan leher. Edisi ke-6. Jakarta: FK UI, 2007; p. $145-53$.

2. Nerwan Dorland WA. Kamus kedokteran Dorland (Edisi Kelima). Indonesia: ECG, 2000; p.2003.

3. Setiyohadi B, Subekti I. Pemeriksaan fisis umum. Dalam: Sudoyo AW, Setiyohadi B, Alwi I, Simadibrata K M, Setiati S, editor. Ilmu penyakit dalam (Edisi Ketiga). Jakarta: Ilmu Penyakit Dalam, 2009; p.42-3.

4. Bhaya MH, Goldsmith AJ. Nyeri kepala dan wajah. Dalam: Lucente FE. Har-El $\mathrm{G}$, editors. Ilmu THT esensial (Edisi Kelima). Jakarta: EGC, 2011; hal.222.

5. Lindbake M. Hickner JM. Ear nose and throat problems. In: Jones R, Britten N, Culpepper L, Grol R, Mant D, Silagy C, et al, editors. Oxford textbook of primary medical care. $2^{\text {nd }}$ volume. New York: Oxford University, 2005; p.72427.

6. Beach J. Sinusitis. In: Buttaro TM, Trybulski J, Bailey PP, Cook JS, editors. Primary care: a collaborative practice (Third Edition).

7. HTA Indonesia. Functional endoscopic sinus surgery di Indonesia [homepage on the Internet]. 2006 [cited 22 oktober 2012]. Available from: http://buk.depkes.go.id/ index.php.

8. Data Poli THT di bagian THT FK UNSRAT BLU RSUP Prof. Dr. R. D. Kandou, Manado 1995.

9. A.D.A.M Medical Encyclopedia. Sinusitis [homepage on the Internet]. 2012 [updated 2012 July 30; diakses 22 oktober 2012]. Available from: http:// www.ncbi.nlm.nih.gov/pubmedhealth/P MH0001670.html.

10. Dhawan VK. Otitis externa otitis media sinusitis. In: Yoshikawa TT, Norman DC, editors. Infectious disease in the aging: a clinical handbook (Second Edition). Los Angeles: Humana press; 2009. p. 297-304.

11. Rachman MD. Sinus paranasal. Dalam: Rasad S, editor. Radiologi diagnostic (Edisi Kedua). Jakarta: FKUI, 2005; hal.431-8.

12. Nasution MTA. Frekuensi penderita rinosinusitis maksila kronis yang disebabkan infeksi jamur [Tesis]. Medan: Fakultas Kedokteran USU/RSU H. Adam Malik; 2007. 
134 Jurnal e-Biomedik (eBM), Volume 1, Nomor 1, Maret 2013, hlm. 129-134

13. Paramita DA, Suyono, Yarsa KY, Mardiatmo, Putranto W. Hubungan antara rhinitis kronis dan gambaran sinusitis pada foto waters. CDK THT. 2010;179:431-3.

14. Munir D, Kurnia B. Pola kuman aerob penyebab sinusitis maksila kronis. CDK THT. 2007;155:69-72.
15. Dalimunthe SA. Gambaran penderita rinosinusitis di RSUP. Haji Adam Malik Medan pada tahun 2010 [Karya Tulis Ilmiah]. Medan: Fakultas Kedokteran USU/RSU H. Adam Malik; 2010. 